\title{
新しい原理・現象に基づく最先端 表面磁性計測法
}

\author{
横山利彦
}

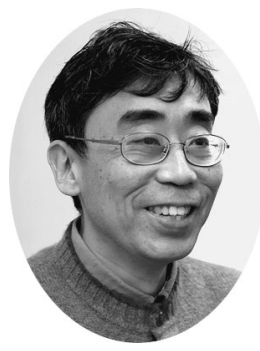

2008 年のノーベル物理学賞は $\mathrm{Fe} / \mathrm{Cr}$ 磁性多層膜の巨大磁気抵抗効果（1988～89 年）の発見 に対して与えられたが，この 20 年のうちに，巨大磁気抵抗効果を利用した薄膜磁気記録素子 （HDD GMR 読取ヘッド）はすべての家庭のパソコンにも導入されるほど，社会への影響は甚 大であった。さらに磁性薄膜の巨大磁気抵抗効果は不揮発性主記憶素子としても実用化が間近 である。今後も磁気記録・記憶の高密度化と高速化は社会的要請として急務であり，全く新た な視点で新規物性を有する磁性体の探索が必須であろう。

磁性薄膜の物性に対する表面・界面の寄与は甚大である。垂直磁化膜は HDD の高密度化に 有効なため既に実用化されているが，磁性薄膜表面への化学吸着により薄膜全体の磁気異方性 が垂直磁化に転移するなどの変化もよく知られている。僅かな表面吸着で磁性薄膜全体の転移 が誘起されることは，他に例を見ない劇的変化である。一方，Fermi 準位でスピン偏極度 100\% を示すハーフメタルは，GMR 素子として高効率化が期待できる素材であるが，表面あ るいは電極界面においても完全スピン偏極性を維持できるかは，非常に重要な今後の検討課題 である。

新規磁気物性の探索に加えて，表面・薄膜磁性計測法自体の新たな開発も同様に急務であ る。産業がさらなる高密度化・高速化を要請するのであれば，より高い時空間分解能と簡便性 を有する測定手法が望まれる。新しい測定手法にも，既存技術の改良に留まらず，全く新たな 視点で新しい現象に基づいたブレークスルーが期待されよう。

本号は表面磁性研究特集号として，特に最先端の表面磁性計測法や現象に関する 5 編の研究 紹介がまとめられており，大変興味深く拝読させていただいた。奥田氏は，スピン偏極光電子 分光で沉用的な Mott 検出器に替わる, 超低速電子線回折を用いた新しいスピン検出器で, 検 出効率の 2 桁もの向上を実現した。内橋氏は，表面磁性不純物の近藤効果が，磁性金属多層膜 の非磁性層量子井戸状態により制御できることを，原子分解能 STS を用いて明らかにした。 米田氏は，STMにより，原子レベルの空間分解能で電子スピン共鳴信号を観測することに成 功し，初期酸化 $\mathrm{Si}$ (111）表面ダングリングボンド上のスピン観測を実証した。中川氏は，放 射光に依らないレーザー紫外光電子磁気円二色性光電子顕微鏡を実現し，超高速時間分解計測 が可能であることを例証した。阿部氏は，樑さ分解 X 線磁気円二色性法に基づいて，化学吸 着が演じる磁性薄膜の不思議な特性を紹介している。いずれも今後の展開が大いに期待でき, 我が国の当該分野での研究レベルの高さが証明されていると思う。

表面磁性の新たな計測法の開発や新物性発見が，表面磁性分野に限らず表面科学全体の基盤 ともなり得る。また，記憶・記録素子の高密度化・高速化への貢献に加えて，全く他の分野へ の将来的な貢献も期待できよう。今後ともブレークスルー的発展を切に望む。

(自然科学研究機構・分子科学研究所)

Novel Characterization Techniques for Surface Magnetism Based on New Principles and Phenomena

Toshihiko Yокоуама (Institute for Molecular Science, National Institutes of Natural Sciences) 